\title{
Soil-Water Charateristics of Tropical Clay Soil under High and Low Suction Conditions
}

\author{
Bamitale Dorcas Oluyemi-Ayibiowu, Taiwo Olawale Akinleye, Olaolu George Fadugba, \\ Ayodeji Stanley Olowoselu
}

Department of Civil Engineering, The Federal University of Technology, Akure, Nigeria

Email: bayibiowu@yahoo.com

How to cite this paper: Oluyemi-Ayibiowu, B. D., Akinleye, T. O., Fadugba, O. G., \& Olowoselu, A. S. (2020). Soil-Water Charateristics of Tropical Clay Soil under High and Low Suction Conditions. Journal of Geoscience and Environment Protection, 8, 162-175.

https://doi.org/10.4236/gep.2020.811010

Received: March 16, 2019

Accepted: November 20, 2020

Published: November 23, 2020

Copyright $\odot 2020$ by author(s) and Scientific Research Publishing Inc. This work is licensed under the Creative Commons Attribution International License (CC BY 4.0).

http://creativecommons.org/licenses/by/4.0/

\begin{abstract}
Tropical clay soil was compacted at different moisture conditions (dry, wet and optimum) and compactive efforts (Reduced proctor, Standard proctor, West African standard and Modified proctor). Experimental Soil-Water Characteristics (SWC) of the soil was derived using the pressure plate extractor equipment and SWC Curves (SWCC) plotted as gravimetric water content versus logarithm of matric suction. The Air Entry Values (A.E.V) obtained from experimental work ranged from $21 \mathrm{kPa}$ to $59 \mathrm{kPa}$ and compared favourably well with those estimated from predictive models with values of 23 $\mathrm{kPa}$ to $52 \mathrm{kPa}$. Specimens compacted with greater compactive effort (Modified proctor) and at optimum moisture content produced the largest air entry value of $59 \mathrm{kPa}$ and reduced air voids. Changes observed in the shape of the SWCC were consistent with changes in pore size which occurred by varying compaction conditions. The shape of the soil-water characteristics curve was found to depend on the soil structure, compactive water content and compactive effort and not solely on the percentage of fine particles.
\end{abstract}

\section{Keywords}

Soil-Water Characteristics, Tropical Clay Soil, Compaction Water Content, Compactive Efforts, Soil-Water Characteristics Curve

\section{Introduction}

Unsaturated soil behaviour is important in the construction of numerous geotechnical and geo-environmental structures such as earth dams, retaining walls, pavements liners and waste soil-covers. An unsaturated soil consists of four-phase system; solids, water, air and contractile skin (Fredlund \& Morgenstern, 1977). Soils in this category are the natural, desiccated and compacted soils with nega- 
tive pore-water pressures and are subject to expansion and shrinkage. Unsaturated soils are found all over the world especially at shallow depths from the surface in arid and semi-arid areas where the natural ground water table is typically at a greater depth (Fredlund \& Rahardjo, 1993).

Compacted natural soils used as hydraulic barriers in waste containment facilities such as engineered landfills are often unsaturated and modeling of flow and transport through these soils require the knowledge of their unsaturated hydraulic properties (Osinubi \& Bello, 2011). The soil-water characteristics can be described as a measure of the water holding capacity (i.e. storage capacity) of the soil as the water content changes when subjected to various values of suction. Precipitation and evaporation set up a moisture flux across the ground surface which directly affects the pore-water pressures in an unsaturated soil (Rahimi et al., 2010; Tang, Qi, Jiang, \& Li, 2015). Evaporation can induce high soil suctions near the ground surface. On the other hand, precipitation can eliminate the soil suction. Due to the hysteretic effect of water filling and draining from the pores, different wetting and drying soil-water characteristics curves may be distinguished.

According to Tinjum et al. (1997), SWCC defines the relationship between matric suction $(\Psi)$ (i.e. difference in the pore air pressure and pore water pressure) and water content (gravimetric $(w)$ or volumetric $(\theta)$ or degree of saturation $(S)$ ) of any soil. It is the plot of the degree of saturation/volumetric water content/gravimetric water content and matric suction of soil. SWCC has repeatedly been identified as the key soil information required for the analysis of seepage, strength characteristics, permeability coefficient, water storage capacity and volume change problems involving unsaturated soils (Barbour, 1998; Fredlund, 2000). It is certainly true that the SWCC is useful to geotechnical and geo-environmental engineering applications, but it is also necessary that the soil-water characteristics curve be properly obtained and interpreted. The engineering properties of these soils get altered due to wetting and drying process depending on their environmental condition. The evaluation of the soil-water characteristics and derivation of the SWCC of these in-situ soils are therefore important, as this curve is the primary constitutive relationship for the prediction of the engineering behaviour of these unsaturated soils.

Numerous laboratory apparatus has been developed to obtain the SWC independently. They are broadly grouped into direct and indirect methods. Direct method includes pressure plate, Buchner funnel, tensiometer and pressure membranes. These methods measure the pore water pressure in the soil or imposed air pressure into the soil. Among these methods, pressure plate extractor is widely used. Indirect methods use measurement or indicator of water content or a physical property that is sensitive to change in water content. Usually, two methods are adopted in using the pressure plate extractor, namely; the method of weighing soil (WSM), which measures the water content by weighing the soil sample when equilibrium is reached, and the method of weighing outflow (WOM), which measures the water content by weighing the outflow from the soil sample 
after equilibrium is attained.

Clay refers to a naturally occurring material composed primarily of fine-grained minerals, which is generally plastic at appropriate water contents and harden when dried or fired. Although clay usually contains phyllosilicates, it may contain other materials that impart plasticity and harden when dried or fired. Clays exhibit plasticity when mixed with water in certain proportions, but when dry, clay becomes firm and when fired in a kiln, permanent physical and chemical changes occur. Clay, being relatively impermeable to water, is also used where natural seals are needed, such as in the cores of dams, or as a barrier in landfills against toxic seepage (lining the landfill, preferably in combination with geotextiles). Recent studies have also investigated clay's absorption capacities in various applications, such as the removal of heavy metals from waste water and air purification.

Over the last 70 years, a number of mathematical models for describing the SWCC have been proposed. Early models such as Burdine (1953), Brutsaert (1966) and Mualem (1976) incorporate equations with two curve-fitting parameters. Although some of them are capable of describing the SWCC well, the lack of a third parameter means that still some assumptions have to be made in order to mathematically describe in a consistent manner a reverse sigmoid curve like the SWCC. Van Genuchten (1980) and the Fredlund and Xing (1994) incorporated a three parameter equation capable of simulating the SWCC better through the whole range of suction from 0 to $106 \mathrm{kPa}$. This was actually exhibited by Leong and Rahardjo (1997) who evaluated the use of several published SWCC equations through a series of regression analyses to fit SWCC curves to experimental data from 12 soils. They concluded that both van Genuchten and Fredlund \& Xing equations provide better fits than the two parameter models do.

Van Genuchten model is expressed as

$$
\begin{gathered}
\theta_{w}=\theta_{r}+\left(\theta_{s}-\theta_{r}\right) S \\
S=\frac{1}{\left[1+(\alpha \Psi)^{n}\right]^{m}} \\
\theta_{w}=\theta_{r}+\frac{\left(\theta_{s}-\theta_{r}\right)}{\left[1+(\alpha \Psi)^{n}\right]^{m}}
\end{gathered}
$$

where $W$ is the volumetric water content, $S$ is the saturated volumetric water content, $r$ is the residual volumetric water content, $S$ is the degree of saturation, $\Psi$ is matric suction, $\alpha$ is the parameter related to the air entry value, $n$ is the parameter related to the pore size distribution of soil, $m$ is the parameter related to the asymmetry of the model curve $\left(m=1-n^{-1}\right)$.

Fredlund and Xing model is expressed as:

$$
S(\%)=\frac{\theta_{W}}{\theta_{S}}=\left[1-\frac{\ln \left(1+\frac{\Psi}{h_{r}}\right)}{\ln \left(1+\frac{1000000}{h_{r}}\right)}\right]\left(\frac{1}{\ln \left[\mathrm{e}+\left(\frac{\Psi}{a}\right)^{n}\right]^{m}}\right)
$$


where $S$ is the degree of saturation, is the volumetric water content at desired suction, is the saturated volumetric water content; is the soil suction $(\mathrm{kPa})$, is the soil suction $(\mathrm{kPa})$ corresponding to the residual water content, $a$ is the soil parameter related to the air entry value of the soil $(\mathrm{kPa}), n$ is the soil parameter controlling the slope at the inflection point in the soil-water characteristic curve, $m$ is the soil parameter related to the residual water content of the soil; and e is the natural number, 2.71818 .

Correction Equation Models for Estimating Van Genucten, Fredlund and Xing fitting Parameters.

Navid Model (Navid et al., 2012)

$$
\begin{gathered}
a=0.0015(w P I)^{3}+0.1028(w P I)^{2}+0.5871(w P I)+11.813 \\
n=0.00011(w P I)^{2}-0.01358(w P I)+1.76987 \\
m=-5 \times 10^{-6}-0.00014(w P I)+0.14745
\end{gathered}
$$

where $P I$ is the plasticity index of soil, $w P I$ (Weighted Plasticity Index) is percent passing sieve No. $200 \times P I(\%)$.

Hernandez Model (Hernandez, 2011)

For plastic soils

$$
\begin{gathered}
a_{f}=10^{\left(0.69-\frac{2.7}{1+\mathrm{e}^{4-0.14 G I}}\right)} \\
b_{f}=10^{\frac{0.78}{1+\mathrm{e}^{6.75-0.19 G I}}} \\
c_{f}=0.03+0.62 \times \mathrm{e}^{-\left(0.82\left(\log a_{f}-0.57\right)^{2}\right)} \\
h_{r}=494+\frac{660}{1+\mathrm{e}^{(4-0.19 G I)}}
\end{gathered}
$$

For non-plastic soils

$$
a_{f}=-967.21 D_{10}^{2}+218.37 D_{10}-2.7
$$

Constraints: if $D_{10}<0.020$ then $a_{f}=1.28$

$$
\begin{gathered}
b_{f}=10^{\left(-0.0075 a_{f}^{3}+0.1133 a_{f}^{2}-0.3577 a_{f}+0.3061\right)} \\
c_{f}=0.0058 a_{f}^{3}-0.0933 a_{f}^{2}+0.4069 a_{f}+0.3481 \\
h_{r}=100
\end{gathered}
$$

MEPDG Model (Witczak et al., 2006)

For plastic soils:

$$
\begin{gathered}
a_{f}=32.835\{\ln w P I\}+32.4386 \\
b_{f}=1.421(w P I)^{-0.3185} \\
c_{f}=-0.2154\{\ln w P I\}+0.7145
\end{gathered}
$$




$$
h_{r f}=100
$$

where $w P I$ is weighted plasticity index with constraints.

If $a_{f}<5$, then $a_{f}$ is 5 , If $c_{f}<0.01$, then $c_{f}$ is 0.035 , If $w P I<2$ For plastic soils a weighted average $a_{f}$ is used for the parameter. For $a_{f}$ parameter the following model was proposed:

$$
\begin{gathered}
a_{f a v g}=a_{f n}+\frac{w P I}{2}\left(a_{f p}-a_{f n}\right) \\
a_{f}=1.1-0.5 \\
a=-2.79-14.1\left(\log D_{20}\right)-1.9 \times 10^{-6} P_{200}^{4.34}+0.055 D_{100} \\
D_{100}=10^{\left[\frac{40}{m_{1}}+\log \left(D_{60}\right)\right]} 1.1-0.5 \\
m_{1}=\frac{30}{\left(\log D_{90}\right)-\left(\log D_{60}\right)}
\end{gathered}
$$

$a_{f}$ is SWCC fitting parameter, $D_{20}$ is the Grain diameter corresponding to $20 \%$ of passing by weight in $\mathrm{mm}, D_{30}$ is the Grain diameter corresponding to $30 \%$ of passing by weight in $\mathrm{mm}, D_{60}$ is the Grain diameter corresponding to $60 \%$ of passing by weight in $\mathrm{mm}, D_{90}$ is the Grain diameter corresponding to $90 \%$ of passing by weight in mm, $D_{200}$ is the Percent passing sieve No. 200.

To obtain $b_{f}$ parameter,

$$
b_{f}=0.936 b-3.8
$$

where $b_{f}=$ SWCC fitting parameter.

$D_{10}=$ Grain diameter corresponding to $10 \%$ of passing by weight, in $\mathrm{mm}$

$$
\begin{gathered}
b=\left\{5.39-0.29 \ln \left[P_{200}\left(\frac{D_{90}}{D_{10}}\right)\right]+3 D_{0}^{0.57}+0.021 P_{200}^{1.19}\right\} \\
D_{0}=10^{\left[\frac{-30}{m_{2}}+\log \left(D_{30}\right)\right]}
\end{gathered}
$$

A number of shallow depth slope and foundation failures have occurred during or just after rainfall (Bordoni et al., 2015; Chien et al., 2015; Huang et al., 2017). Some of these failures are caused not only by an increase of positive pore water pressure in soils resulting from a rise in the ground water level but also as a result of a decrease in the pore-water pressure. Soils found in the tropics such as Collapsible soils, expansive clays and residual soils are known to exhibit volume change due to variation in moisture condition (Conte \& Troncone, 2012; Cuomo \& Sala, 2013; Kalenchuk et al., 2013; Oh \& Lu, 2015; Conte et al., 2017). These volume changes cause distress to Civil Engineering structures that are built on them and affect their durability. Therefore, for safety purposes, stability of such structures is paramount. It is thus very important to investigate the behaviour of these soils under fluctuating moisture conditions. This study investigates the soil-water characteristics of typical unsaturated tropical clay soils under low and high suction. 


\section{Materials and Methods}

\subsection{Collected Sample Location}

Tropical clay soils examined in this study were collected at Bayduk area, Akure-Ilesa road, Akure South Local Government Area of Ondo State. Samples were collected using the method of disturbed sampling and were obtained at a depth of about 1 meter below the ground level. Akure is the administrative capital of Ondo State. The area is predominantly hilly and studded with large granite formation, rising to $410 \mathrm{~m}$ above sea level respectively (Oluyemi-Ayibiowu \& Fadugba, 2016). These granite formations are said to be of volcanic origin, underlain by basement complex rocks, which are mostly impermeable gneisses and granites. It is underlain by Precambrian basement complex rocks of south western Nigeria. The major types of rocks in Akure are granite rocks and charnokites. The granite rocks which are members of the older granite suit occupy about $65 \%$ of the total area of Akure. Three principal petrographic varieties are recognized; the fine-grained biotite, granite, medium to coarse grained non-porphyritic biotite-hornblende granite and coarse-porphyritic biotite-hornblade granite. Most soils found in this area are composed largely of residual soils which are weathered products of basement rocks.

\subsection{Test Material and Procedure}

Sample collected $(100 \mathrm{~kg})$ was crushed into smaller pieces and oven dried. Laboratory analysis was then carried out to determine the soil's index and geotechnical properties. The mineral composition was obtained with the aid of a X-ray diffractometer, soil structure was investigated using the scanning electron microscope while soil-water characteristics were analyzed by axis translation technique using the pressure plate extractor device.

All tests were carried out in accordance with the BS 1377:1990 (Soil for Civil Engineering Purposes), and were classified using the American Association of State Highway Officials method (AASTHO), and the Unified Soil Classification System (USCS). Compaction on specimens was achieved by mixing the relevant quantity of dry samples previously crushed to pass through BS sieve No.4 and $4.76 \mathrm{~mm}$ aperture. They were then molded at water content in the range $5.5 \%$ to $25.5 \%$ and four different compactive efforts similar to those that might be achieved in the field.

\section{Pressure Plate Extractor Testing Procedure}

Soil specimens were prepared at $-2,0$ and +2 from dry to the wet side of the line of OMC. $2.5 \mathrm{~kg}$ of each specimen was moistened with their appropriate OMC, mixed thoroughly and compacted in BS moulds using four compactive efforts (reduced proctor, standard proctor, West African standard and modified proctor) and later cored into stainless steel rings with inside diameters of $50 \mathrm{~mm}$ and height $50 \mathrm{~mm}$ with the aid of a mallet. The soil specimens were covered with caps at both ends before saturation. For the drying test, each batch of sample was subjected to full saturation by capillary action for a period of three weeks. The 
air-entry ceramic disk and soil were first saturated. After saturation, excess water was removed from the cell. The soil specimen was placed on the high air-entry ceramic disk inside the retaining cylinder and the cell cover mounted and tightened. At various series of increments, air pressure was applied to the soil to obtain different matric suctions $(\Psi)$. Increase in air pressure caused water to be dispersed from the specimen until an equilibrium state was obtained. The soil specimens were subjected to pressures of 10,30,100,500, 1000 and $1500 \mathrm{kPa}$, respectively. The equipment was disassembled after test completion, the soil specimens removed and placed in an oven to determine their final gravimetric water content. Pressure application for each batch of specimen lasted about two (2) weeks, while the entire procedure from specimen preparation, saturation and pressure application lasted about three (3) months. Pressure was applied using regulated compressed air from a compressor.

\section{Results and Discussion}

The specific gravity of the soil sample was found to be 2.52 . This value is moderately low and suggests the presence of organic matter in the soil. Atterberg limits result shows that the clay soil exhibited high plasticity as indicated by Liquid Limit 60\%, Plastic Limit 46\% and Plasticity Index 14. The soil contained about $0.65 \%$ gravelly material, $33.85 \%$ medium size/coarse material and $65.5 \%$ fine grained material. According to AASHTO classification system, the soil is classified as A-7-6 material while unified soil classification system (USCS), classifies the soil as $\mathrm{OH}$. On the basis of Casangrande plasticity chart, these soils are Organic clays of medium to high plasticity, organics silts. Summary of the index property of the soil is presented in Table 1.

The summary of the compaction characteristics is shown in Table 2. The modified proctor produced the highest maximum dry densities for all soil tested $\left(1.54 \mathrm{mg} / \mathrm{m}^{3}\right)$ at correspondingly lowest optimum moisture content (13.25\%). It can be inferred that maximum dry densities of the soils were influenced slightly

Table 1. Index property of soil.

\begin{tabular}{cc}
\hline Properties & Result \\
\hline Specific Gravity & 2.52 \\
Liquid Limit, \% & 60 \\
Plastic Limit, \% & 46 \\
Plasticity Index, \% & 14 \\
\% Passing BS No. 4 sieve & 100 \\
\% Passing BS No. 10 sieve & 99.45 \\
\% Passing BS No. 40 sieve & 91.34 \\
\% Passing BS No. 200 sieve & 65.50 \\
AASHTO classification & A-7-6 \\
USCS classification & OH \\
Group index & 18 \\
\hline
\end{tabular}


Table 2. Compaction characteristics of soil samples.

\begin{tabular}{ccc}
\hline \multirow{2}{*}{ Compactive Efforts } & \multicolumn{2}{c}{ Soil Sample } \\
\cline { 2 - 3 } & Maximum dry density $\left(\mathrm{Mg} / \mathrm{m}^{3}\right)$ & Optimum moisture content (\%) \\
\hline Reduced Proctor & 1.49 & 13.40 \\
Standard Proctor & 1.16 & 16.40 \\
West African Standard & 1.20 & 13.40 \\
Modified Proctor & 1.54 & 13.25 \\
\hline
\end{tabular}

with the compactive energy utilized, the number of blows and the falling height of rammer.

Rock forming mineral Quartz was dominant in the soil with $72 \%$ and non-expansive clay mineral Kaolinite with $28 \%$. The soil sample was observed to have flaky shape particles with very small thickness relative to the length and breadth. Results showed that the soil sample has dispersed particles having both the macro and micro structure present.

\subsection{Result Obtained from Predictive Models}

The prediction of soil-water characteristics curves was accomplished by the proposed models; Van Genuchten model (1980) and Fredlund and Xing model (1994). Correlation equations by Navid et al. (2012), Zapata (1999), Witczak et al. (2006) and Hernandez (2011) were used to obtain the fitting parameters of the models. The correlation equations were developed using soil index properties such as particle size distribution, Aterberg limit parameters and percentage passing sieve No. 200. Soil water characteristics curve parameters obtained from the correlation equations were fitted by either Van Genuchten model (1980) or Fredlund \& Xing model (1994).

1) Navid Model (Navid et al., 2012)

Navid et al. (2012) developed correlation equations for predicting SWCC parameters based on weighted plasticity index of soils using Van Genuchten model for curve fitting constants parameters. Table 3 shows the soil characteristics and Van Genuchten equation parameters which were computed with the proposed correlation equations. SWCC obtained from Navid et al. model is presented in Figure 1.

2) Zapata Model (Zapata, 1999) and MEPNG Model (Witczak et al., 2006)

Fredlund and Xing (1994) model equation parameters were computed from the proposed correlation equations for both models. Curve fitting parameters for both models were estimated using weighted plasticity index ( $w P I)$ of soils. Soil index properties and Fredlund and Xing constant parameters estimated from both correlation equations are presented in Table 4. Suction values were assumed for the estimation of degree of saturation using the constant parameters obtained, suction/degree of saturation pair of values were plotted to obtain soil water characteristics curve for both correlation equation and for the soil samples. Figure 2 and Figure 3 shows the soil-water characteristic curves for the soils. 
Table 3. Soil characteristics and Van Genutchen constant parameters.

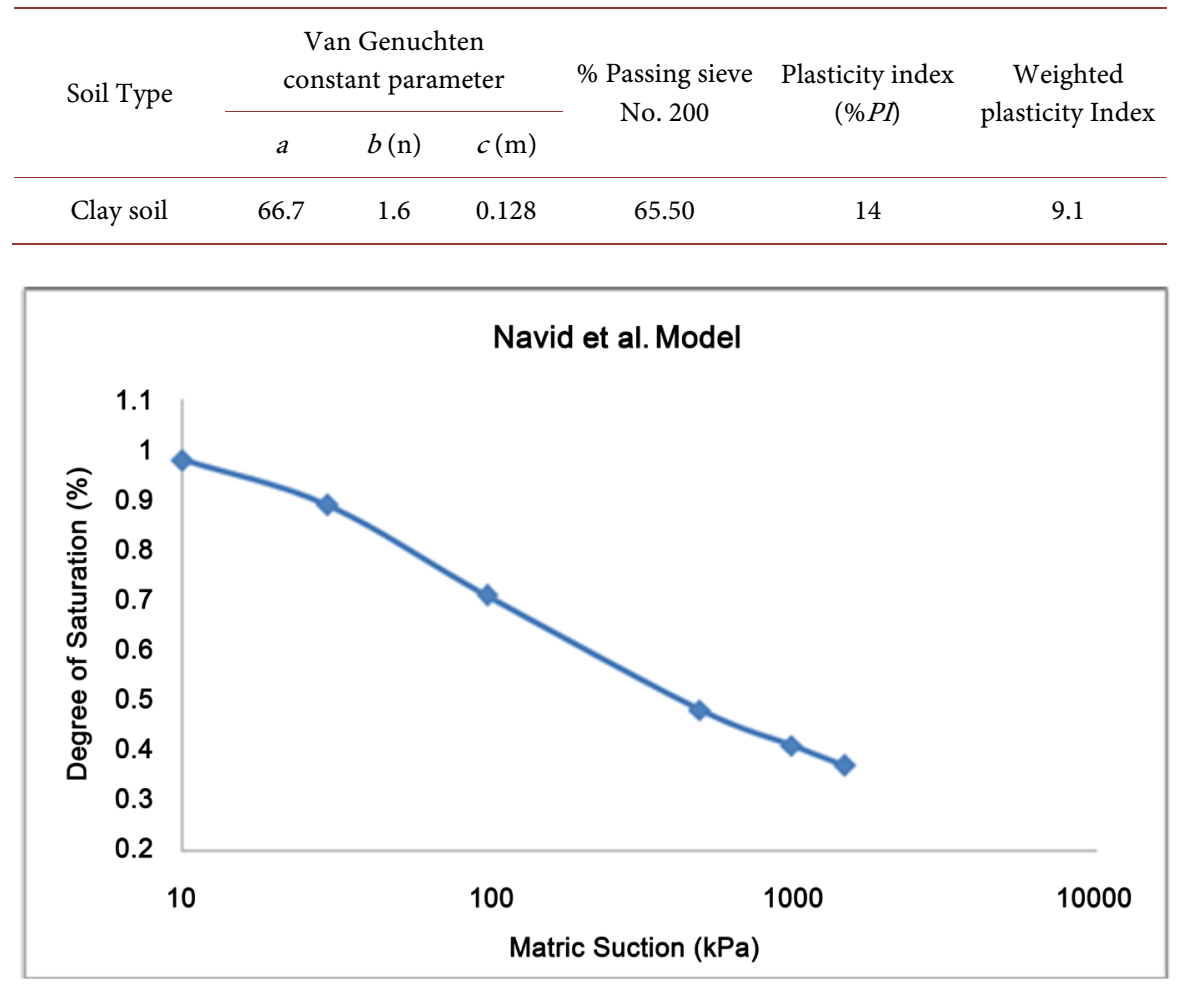

Figure 1. Soil-water characteristic curves for soil samples using Navid et al. Model.

Table 4. Soil index properties and fredlund \& xing model estimated constant parameters.

\begin{tabular}{|c|c|c|c|c|c|c|c|c|c|c|c|}
\hline \multirow{2}{*}{$\begin{array}{l}\text { Soil } \\
\text { type }\end{array}$} & \multicolumn{3}{|c|}{$\begin{array}{l}\text { Zapata (1999) model } \\
\text { Constant parameters }\end{array}$} & \multicolumn{4}{|c|}{$\begin{array}{l}\text { Witczak et al., (2006) } \\
\text { Constant parameters }\end{array}$} & \multicolumn{4}{|c|}{ Soil Index Properties } \\
\hline & $a_{f}$ & $b_{f}$ & $c_{f}$ & $h_{r f}$ & $a_{f}$ & $b_{f}$ & $c_{f}$ & $h_{r f}$ & $P_{200}(\mathrm{~W})$ & $P I(\%)$ & ${ }_{w} P I(\%)$ \\
\hline Clay & 7.66 & 1.91 & 0.64 & 291 & 104.95 & 0.70 & 0.24 & 500 & 65.50 & 14 & 9.1 \\
\hline
\end{tabular}

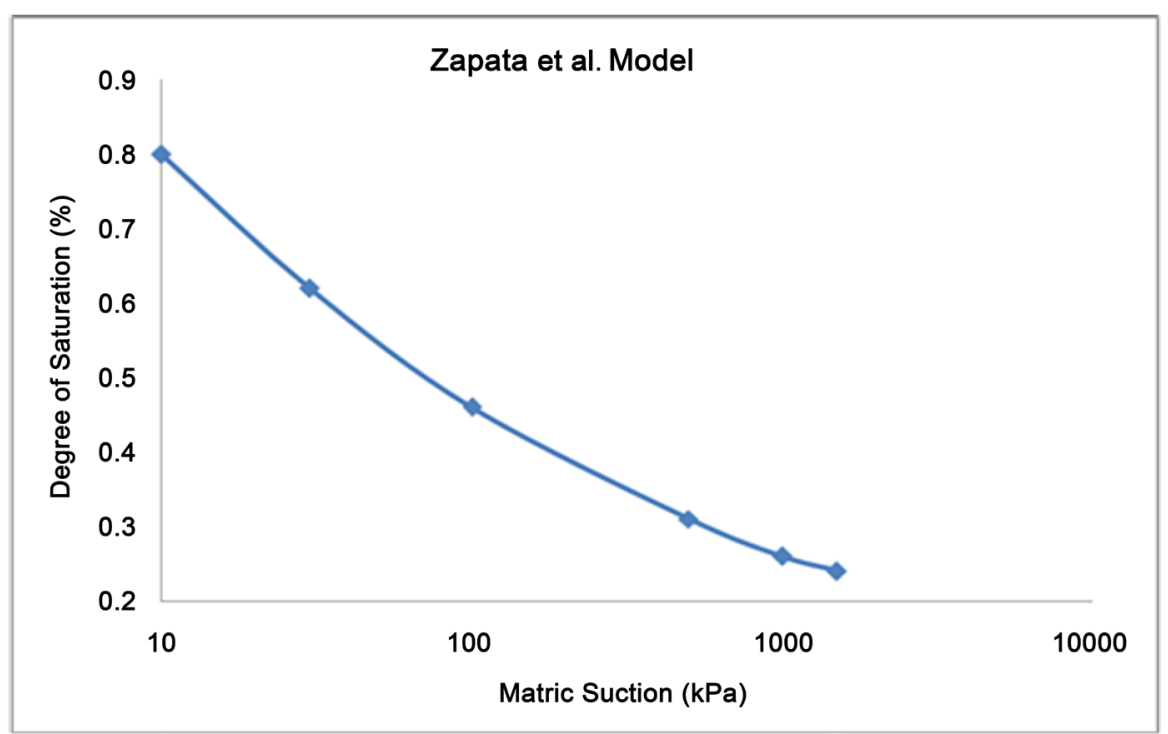

Figure 2. Soil-Water Characteristic Curves for soil sample using Zapata et al. Model. 
3) Hernandez Model (Hernandez, 2011)

Hernandez in 2011 proposed models for the soil water characteristic fitting parameter as expressed in Fredlund and Xing (1994). The model is based on the Group index of soils. The group index was obtained using soil index properties. Soil water characteristics curve parameters obtained from the correlation equations were fitted by Fredlund and Xing model (1994). Soil characteristics and Hernandez equation parameters which were computed with the proposed correlation equations are shown in Table 5 . Figure 4 shows the soil-water characteristic curves for the soil sample.

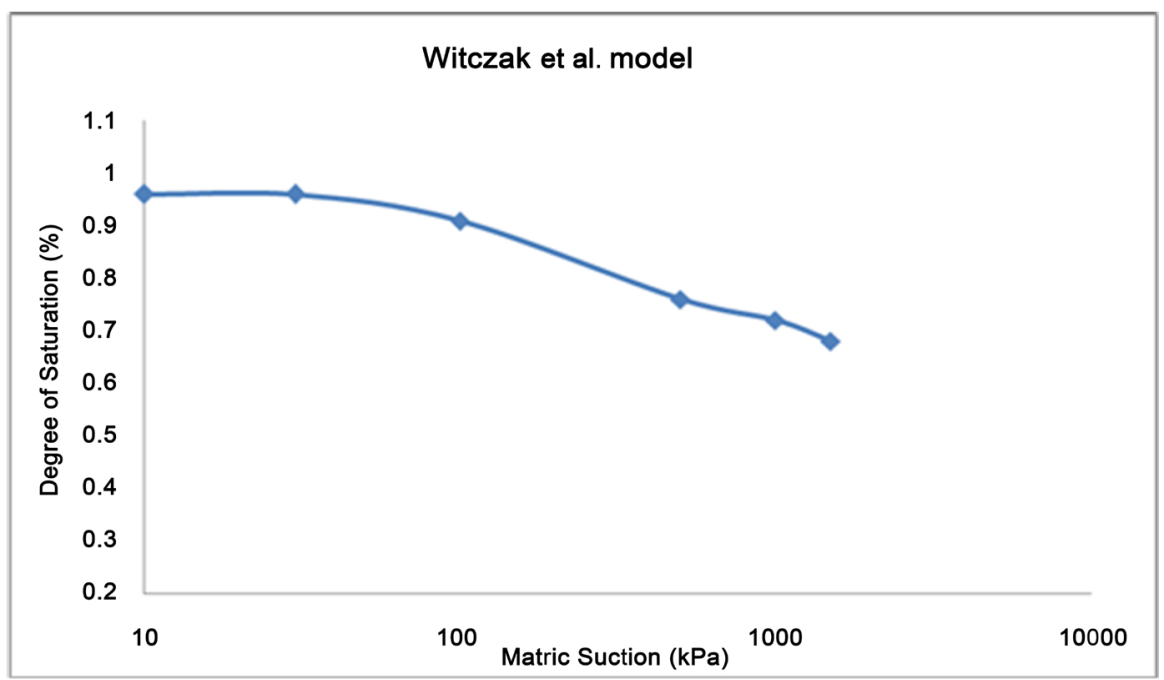

Figure 3. Soil-Water Characteristic Curves for soil sample using Witczak et al. Model.

Table 5. Soil index properties and fredlund \& xing model estimated constant parameters.

\begin{tabular}{|c|c|c|c|c|c|c|c|}
\hline \multirow{2}{*}{ Soil Type } & \multicolumn{4}{|c|}{ Fredlund \& Xing Constant parameters } & \multirow{2}{*}{$\begin{array}{c}\% \text { Passing } \\
\text { sieve No. } 200\end{array}$} & \multirow{2}{*}{$\begin{array}{c}\text { Plasticity } \\
\text { index }(\% P I)\end{array}$} & \multirow{2}{*}{$\begin{array}{c}\text { Weighted plasticity } \\
\text { Index }(w P I)\end{array}$} \\
\hline & $a_{f}$ & $b_{f}$ & $c_{f}$ & $h_{r f}$ & & & \\
\hline Clay & 1.55 & 1.51 & 0.58 & 730.90 & 65.50 & 14 & 9.1 \\
\hline
\end{tabular}

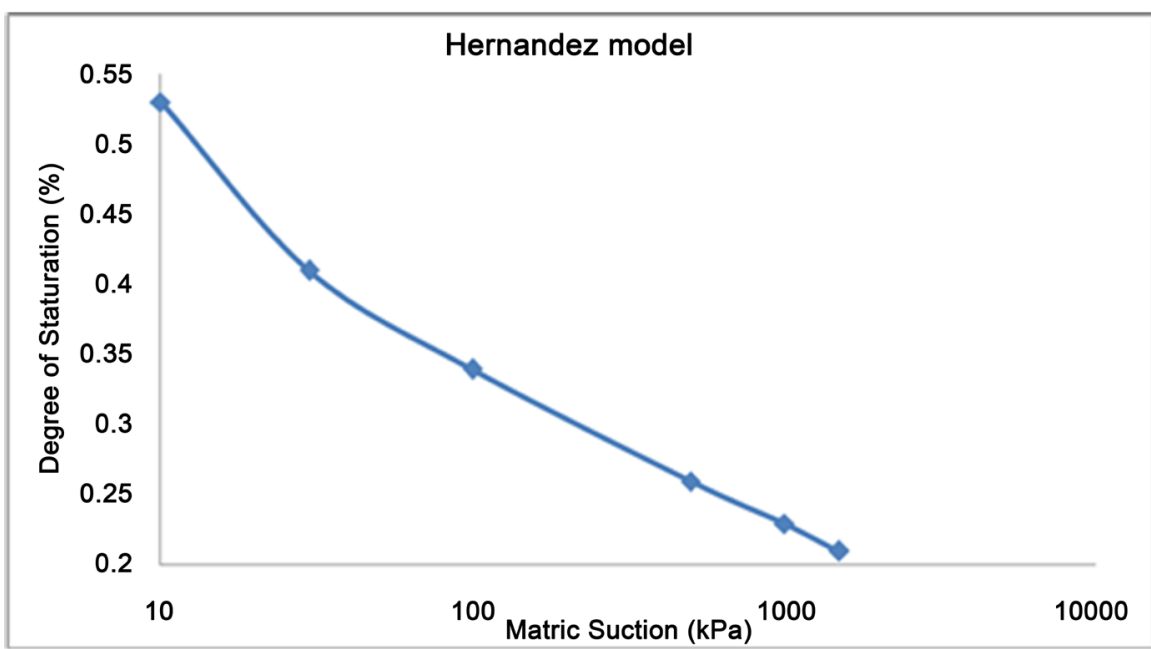

Figure 4. Soil-water characteristic curves for soil samples using Hernandez model. 


\subsection{Discussion on the Predictive Models Used for Obtaining SWCC}

The air entry values obtained from the predictive models for all the soils are presented in Table 6. The two SWCC models based their correlation equations on index properties of soil. Precisely, the correlation equations were built mainly on weighted plasticity index ( $w P I)$ for plastic soils and particle diameter of soils at some stated percent finer.

The degree of saturation values obtained at assumed suction values for Van Genuchten (1980) model and Fredlund and Xing (1994) Model decreased gradually for all soils up to a suction of $1500 \mathrm{kPa}$ as measured in this study. Result showed that at $1500 \mathrm{kPa}$, soils still contain certain degree of moisture and this is in accordance with theoretical and experimental proven fact that at a suction of $1,000,000 \mathrm{kPa}$, the degree of saturation for any soil is zero (0\%). Moderate differences were observed in the air entry values obtained (range $4 \mathrm{kPa}$ to $52 \mathrm{kPa}$ ); the air entry values obtained from Witczak et al. (2006) model were the highest for all the soils with $52 \mathrm{kPa}$ as shown in Table 6 .

\subsection{Comparism of Experimental and Predicted Results}

The curves obtained from experimental study are in conformity with that obtained for reddish tropical soils by Osinubi and Bello (2011). The air entry values obtained (range $21 \mathrm{kPa}$ to $59 \mathrm{kPa}$ ) from experimental work, using the Pressure Plate Extractor compared favourably well with those estimated from predicted models (range $23 \mathrm{kPa}$ to $52 \mathrm{kPa}$ ) but with slight variations as shown in Table 6 and Table 7. The results obtained from Hernandez (2011) model (air entry value of 32 $\mathrm{kPa}$ and $600 \mathrm{kPa}$ residual suction value, were the closest to experimental results (average air entry value of $34 \mathrm{kPa}$ and $800 \mathrm{kPa}$ residual suction value). Van Genuchten (1980) and Fredlund and Xing (1994) model using Hernandez and Navid et al. (2012) parameter fitting equations provided the best result for the Soil.

Table 6. Summary of Air Entry Values (A.E.V) and Residual Suction (R.S) of soil obtained from predicted SWCC correlation Equations.

\begin{tabular}{ccccccccc}
\hline \multirow{2}{*}{$\begin{array}{c}\text { Soil } \\
\text { Type }\end{array}$} & $\begin{array}{c}\text { Navid et al. (2012) } \\
\text { (Van Genucthen })\end{array}$ & \multicolumn{2}{c}{ Fredlund \& Xing } & $\begin{array}{c}\text { Witczak et al. (2006) } \\
\text { Fredlund \& Xing }\end{array}$ & $\begin{array}{c}\text { Hernandez (2011) } \\
\text { Fredlund \& Xing }\end{array}$ \\
\cline { 2 - 9 } & $\begin{array}{c}\text { A.E.V } \\
(\mathrm{kPa})\end{array}$ & $\begin{array}{c}\text { R.S } \\
(\mathrm{kPa})\end{array}$ & $\begin{array}{c}\text { A.E.V } \\
(\mathrm{kPa})\end{array}$ & $\begin{array}{c}\text { R.S } \\
(\mathrm{kPa})\end{array}$ & $\begin{array}{c}\text { A.E.V } \\
(\mathrm{kPa})\end{array}$ & $\begin{array}{c}\text { R.S } \\
(\mathrm{kPa})\end{array}$ & $\begin{array}{c}\text { A.E.V } \\
(\mathrm{kPa})\end{array}$ & $\begin{array}{c}\text { R.S } \\
(\mathrm{kPa})\end{array}$ \\
\hline Clay & 40 & 450 & 23 & 420 & 52 & 720 & 32 & 600 \\
\hline
\end{tabular}

Table 7. Air entry value and residual suction value of samples.

\begin{tabular}{|c|c|c|c|c|c|c|c|c|c|}
\hline \multirow{2}{*}{$\begin{array}{c}\text { Soil } \\
\text { Type }\end{array}$} & \multirow{2}{*}{$\begin{array}{l}\text { Moisture } \\
\text { Condition }\end{array}$} & \multicolumn{2}{|c|}{ WAS } & \multicolumn{2}{|c|}{ SP } & \multicolumn{2}{|c|}{$\mathrm{RP}$} & \multicolumn{2}{|c|}{ MP } \\
\hline & & $\begin{array}{l}\text { A.E.V } \\
(\mathrm{kPa})\end{array}$ & $\begin{array}{c}\text { R.S } \\
(\mathrm{kPa})\end{array}$ & $\begin{array}{l}\text { A.E.V } \\
(\mathrm{kPa})\end{array}$ & $\begin{array}{l}\text { R.S } \\
(\mathrm{kPa})\end{array}$ & $\begin{array}{l}\text { A.E.V } \\
(\mathrm{kPa})\end{array}$ & $\begin{array}{c}\text { R.S } \\
(\mathrm{kPa})\end{array}$ & $\begin{array}{l}\text { A.E.V } \\
(\mathrm{kPa})\end{array}$ & $\begin{array}{l}\text { R.S } \\
(\mathrm{kPa})\end{array}$ \\
\hline \multirow{3}{*}{ Clay } & Opt. & 32 & 900 & 42 & 110 & 21 & 700 & 59 & 900 \\
\hline & Dry of Opt. & 31 & 750 & 33 & 950 & 29 & 950 & 32 & 1010 \\
\hline & Wet of Opt. & 32 & 130 & 37 & 800 & 26 & 950 & 38 & 1000 \\
\hline
\end{tabular}




\subsection{Conclusion}

Matric suction decreases with an increase in water content tropical clay soils. At matric suction of $1500 \mathrm{kPa}$ (High suction range) the soil samples contained certain degree of moisture; thus, it can be inferred that most in-situ tropical soil exists mostly in an unsaturated state. The dry of optimum specimens exhibit a steeper soil-water characteristics curve when compared with specimens compacted at optimum and wet of optimum water contents. The soil at moisture content below the optimum behaves like a coarse grained soil because the aggregates are closely packed together. The soil structure was influenced considerably by the initial molding water content. Specimen compacted dry of optimum had the highest pore size distribution. Air-entry value was observed to be affected more by the arrangement of compacted soil and not solely on the percentage of fine particles. From experiment result soil-water characteristics curve can be said to be dependent mainly on the compaction and molding water content of the soil. Hernandez correlation equation was best suited for estimating the soil water characteristics curve for high plastic tropical soils.

\section{Conflicts of Interest}

The authors declare no conflicts of interest regarding the publication of this paper.

\section{References}

Barbour, S. L. (1998). The Soil-Water Characteristics Curve: A Historical Perspective, Nineteenth Canadian Geotechnical Colloquium. Canadian Geotechnical Journal, 35, 873-894. https://doi.org/10.1139/t98-040

Bordoni, M., Meisina, C., Valentino, R., Lu, N., Bittelli, M., \& Chersich, S. (2015). Hydrological Factors Affecting Rainfall-Induced Shallow Landslides: From the Field Monitoring to a Simplified Slope Stability Analysis. Engineering Geology, 193, 19-37. https://doi.org/10.1016/j.enggeo.2015.04.006

Brutsaert, W. (1966). Probability Laws for Pore Size Distributions. Soil Science, 101, 85-92. https://doi.org/10.1097/00010694-196602000-00002

Burdine, N. T. (1953). Relative Permeability Calculations from Pore Size Distribution Data. Journal of Petroleum Technology, 5, 71-77. https://doi.org/10.2118/225-G

Chien, L. K., Hsu, C. F., \& Yin, L. C. (2015). Warning Model for Shallow Landslides Induced by Extreme Rainfall. Water, 7, 4362-4384. https://doi.org/10.3390/w7084362

Conte, E., \& Troncone, A. (2012). A Method for the Analysis of Soil Slips Triggered by Rainfall. Geotechnique, 62, 187-192.

Conte, E., Donato, A., \& Troncone, A. (2017). A Simplified Method for Predicting Rainfall-Induced Mobility of Active Landslides. Landslides, 14, 35-45.

https://doi.org/10.1007/s10346-016-0692-8

Cuomo, S., \& Sala, M. D. (2013). Rainfall-Induced Infiltration, Runoff and Failure in Steep Unsaturated Shallow Soil Deposits. Engineering Geology, 162, 118-127. https://doi.org/10.1016/j.enggeo.2013.05.010

Fredlund, D. G. (2000). The Implementation of Unsaturated Soil Mechanics into Geotechnical Engineering. Canadian Geotechnical Journal, 37, 963-986. 
https://doi.org/10.1139/t00-026

Fredlund, D. G., \& Morgenstern, N. R. (1977). Stress State Variables for Unsaturated Soils. Journal of Geotechnical Engineering, 103, 447-466.

Fredlund, D. G., \& Rahardjo, H. (1993). Soil Mechanics for Unsaturated Soils. Wiley-Interscience Publications, Hoboken, NJ. https://doi.org/10.1002/9780470172759

Fredlund, D. G., \& Xing, A. (1994). Equations for the Soil-Water Characteristic Curve. Canadian Geotechnical Journal, 31, 521-532. https://doi.org/10.1139/t94-061

Hernandez, G. T. (2011). Estimating the Soil-Water Characteristics Curve Using Grain Size Analysis and Plasticity Index. M.Sc. Thesis, Department of Civil Engineering, Tempe, AZ: Arizona State University.

Huang, F., Luo, X., \& Liu, W. (2017). Stability Analysis of Hydrodynamic Pressure Landslides with Different Permeability Coefficients Affected by Reservoir Water Level Fluctuations and Rainstorms. Water, 9, 450. https://doi.org/10.3390/w9070450

Kalenchuk, K. S., Hutchinson, D. J., \& Diederichs, M. S. (2013). Downie Slide: Numerical Simulation of Groundwater Fluctuations Influencing the Behaviour of a Massive Landslide. Bulletin of Engineering Geology and the Environment, 72, 397-412. https://doi.org/10.1007/s10064-013-0484-5

Leong, E. C., \& Rahardjo, H. (1997). Review of Soil-Water Characteristic Curve Equations. Journal of Geotechnical and Geoenvironmental Engineering, 123, 1106-1117. https://doi.org/10.1061/(ASCE)1090-0241(1997)123:12(1106)

Mualem, Y. (1976). A New Model for Predicting Hydraulic Conductivity of Unsaturated Porous Media. Water Resources Research, 12, 513-522. https://doi.org/10.1029/WR012i003p00513

Navid, G., Yadolla, P. P., \& Seyed, M. H. (2012). Prediction of Soil-Water Characteristics Curve Based on Soil Index Properties. In T. Schanz (Ed.), Experimental Unsaturated Soil Mechanics. Springer Proceedings in Physics, Berlin, Heidelberg: Springer.

Oh, S., \& Lu, N. (2015). Slope Stability Analysis under Unsaturated Conditions: Case Studies of Rainfall-Induced Failure of Cut Slopes. Engineering Geology, 184, 96-103. https://doi.org/10.1016/j.enggeo.2014.11.007

Oluyemi-Ayibiowu, B. D., \& Fadugba, O. G. (2016). Assessment of the Engineering Characteristics of Coarse Aggregates in Akure Township. European International Journal of Science and Technology, 5, 171-180.

Osinubi, K. J., \& Bello, A. A. (2011). Soil-Water Characteristics Curves for Reddish Brown Tropical Soils (Vol. 16). Berlin: Springer, 1-25.

Rahimi, A., Rahardjo, H., \& Leong, E. C. (2010). Effect of Hydraulic Properties of Soil on Rainfall-Induced Slope Failure. Engineering Geology, 114, 135-143. https://doi.org/10.1016/j.enggeo.2010.04.010

Tang, D., Qi, X. H., Jiang, S. H., \& Li, D. (2015). Influence of Different Antecedent Rainfall and Soil Water Characteristic Curve on Slope Stability. Chinese Journal of Geotechnical Engineering, 37, 148-155.

Tinjum, J. M., Benson, C. H., \& Blotz, L. R. (1997). Soil Water Characteristics Curves for Compacted Clays. Journals of Geotechnical and Geoenvironmental Engineering, 123, 1060-1069. https://doi.org/10.1061/(ASCE)1090-0241(1997)123:11(1060)

Van Genuchten, G. (1980). A Closed-Form Equation for Predicting the Hydraulic Conductivity of Unsaturated Soil. Soil Science Society of American Journal, 44, 892-898. https://doi.org/10.2136/sssaj1980.03615995004400050002x

Witczak, M. W., Zapata, C. E., \& Houston, W. N. (2006). Models Incorporated into the 
Current Enhanced Integrated Climatic Model: NCHRP 9-23 Project Findings and Additional Changes after Version 0.7, Final Report. Project NCHRP 1-40D. Inter Team Technical Report. |Tempe, AZ: Arizona State University.

Zapata, C. E. (1999). Uncertainty in Soil-Water Characteristic Curve and Impacts on Unsaturated Shear Strength Predictions. Ph.D. Dissertation, Tempe, AZ: Arizona State University. 